\title{
All Kinds of Satyrs
}

\section{The First Decades of the 5 th Century}

\section{The Painters of Large Vases}

The great significance of Dionysiac imagery becomes strikingly evident when we consider the work of the Kleophrades Painter and the Berlin Painter, two leading painters of large vases such as the amphora, the more distinguished krater types, and the stamnos. Both artists also painted Panathenaic prize amhorae, commissioned by the polis, which is an indication of the eminent position they held at the Kerameikos of Athens already in their own time. It is, therefore, no coincidence that the earliest known pointed amphora is the work of the Kleophrades Painter. ${ }^{1}$ The pointed amphora, one of the rarest and most valuable types of vases, was inspired by the prize amphora. We will discuss this vase type below. ${ }^{2}$

The Kleophrades Painter was probably a pupil of Euthymides and active between 505 and 475 BC. ${ }^{3}$ He painted a multi-figure version of the return of Hephaistos to the Olympus on two of his many calyx kraters, which, unfortunately, have mainly been preserved in a fragmentary state. ${ }^{4}$ Calyx kraters belonged to the most sumptuous vase types of the time. On the one Beazley considers a very early work ${ }^{5}$ the Kleophrades Painter depicted both Hephaistos and Dionysos, each on one side of the vase, as Lydos did on his large column krater, now in New York. ${ }^{6}$ They are accompanied by eight satyrs, whose attributes - musical instruments, symposium vessels, and the tools of the smith - subtly refer to the analogy between wine and fire and in this way to the close relationship between Hephaistos, the divine smith, and Dionysos, the god of the symposium. ${ }^{7}$ Interestingly, Dionysos here wears a short chiton underneath the panther skin, which is the way he is depicted in the

1 Munich 8732 (2344): Addenda 186 (182.6); BA 201659.

2 See below Chapter 4.

3 Boardman 1981, 93.

4 ARV 185 f., 31-49.

5 Harvard 1960.236: Addenda 187 (185.31); вA 201683; Huber 1992, 63.

6 New York 31.11.11: Addenda 29 (108.5); BA 310151; Isler-Kerényi 2004a, 51-56.

7 Lissarrague 1990, 203, pl. 23 . 


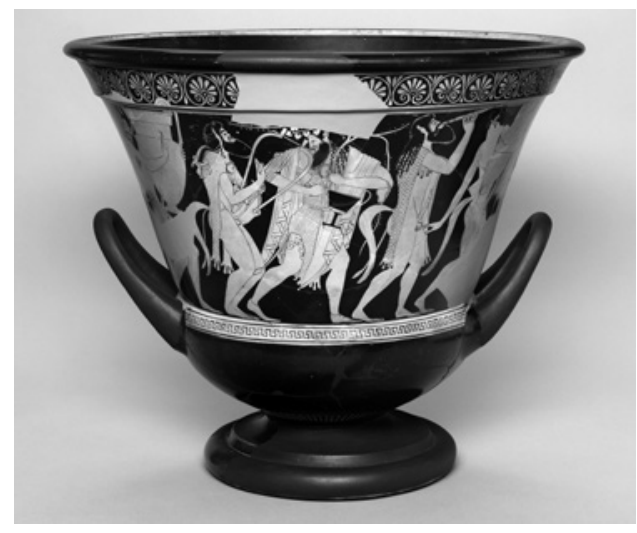

$a$

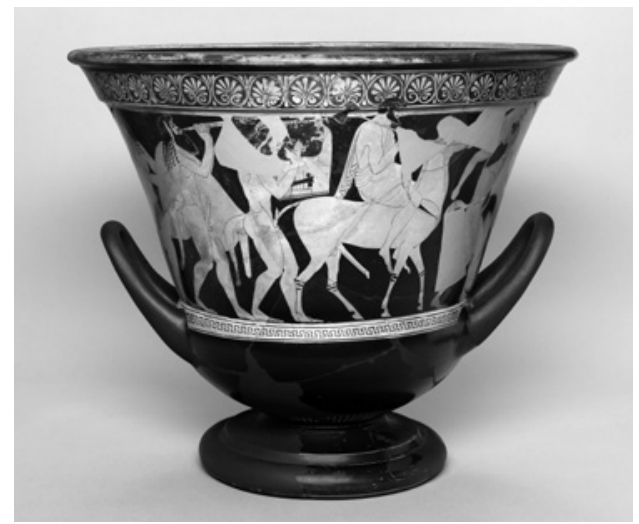

$c$

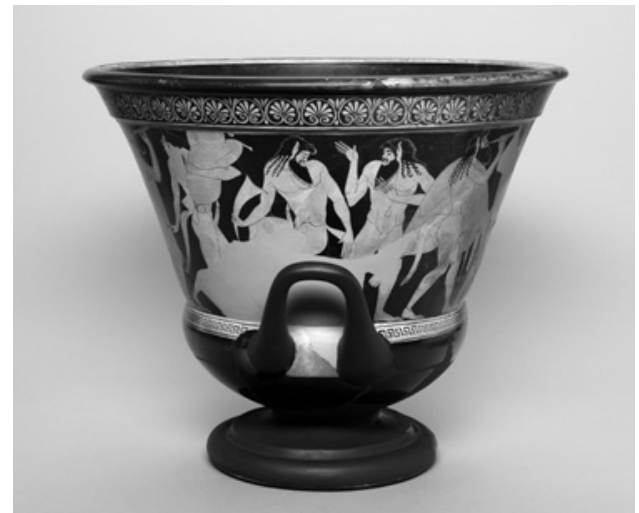

$b$

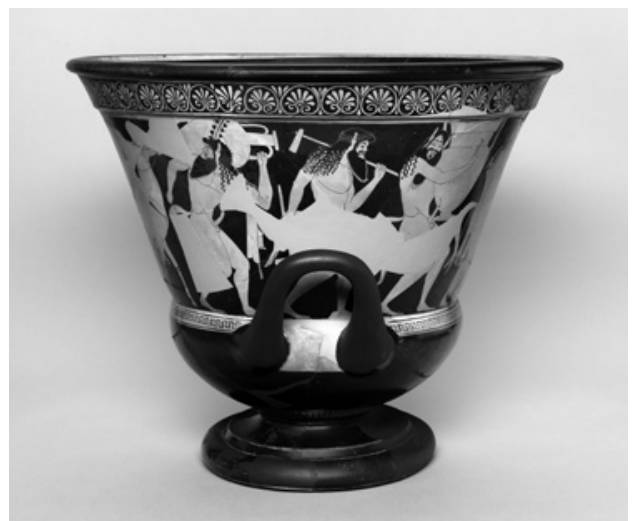

$d$

FIGURE 17 Calyx krater, Kleophrades Painter, Harvard Art Museum, Arthur M. Sackler Museum, Gift of Frederick M. Watkins, 1960.236 (photographs Imaging Department (C) President and Fellows of Harvard College).

a. side A: Dionysos.

b. side view (right).

c. side B: Hephaistos.

d. side view (left).

Gigantomachy. ${ }^{8}$ One of the satyrs, carrying a heavy volute krater, looks out of the image and in doing so directly addresses the viewer (Figure 17).

8 Compare Carpenter 1997, pl. 1B, 2A, 7A-B, and, more than a generation earlier, the frieze of the Siphnian Treasury, LIMC III, Dionysos 651. Compare also a running bearded Dionysos in a short chiton, probably hastening to the scene of combat, on a somewhat younger calyx krater by the Oreithyia Painter in Agrigento C 1538: Para 380 (497.7); BA 205992. 
This same event is presented in an even more elaborate manner on a later calyx krater. ${ }^{9}$ On the one side we see Hephaistos, preceded by Hermes. Rather clumsily in sidesaddle, he rides towards Hera stuck to her throne. Dionysos, visibly intoxicated, is the central figure on the other side. He leans on a satyr, who carries smiths' tools. The satyrs have been joined by two ecstatically dancing maenads. In these two very original versions of the myth, Hephaistos' tools indicate that the images depict the mythical event and not, for instance, a ritual re-enactment. ${ }^{10}$ As in the François krater, Dionysos' course of action not only brings about the reconciliation of the Olympian family, but also the introduction to the Olympus of the satyrs and their female partners. ${ }^{11}$

Further examples of the early work of the Kleophrades Painter are two psykters, one of them depicting a multi-figure thiasos. ${ }^{12}$ The other shows Herakles approaching Dionysos at a symposium with satyrs in attendance. The latter are moving towards the right in a rather peculiar manner: they seem to glide on their knees while making the familiar gesture of surprised recognition or salute known since the 6th century, as if this were the chorus of a satyr play. ${ }^{13}$

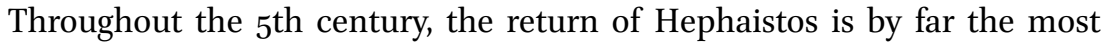
popular among the scarce depictions of episodes from Dionysiac mythology. ${ }^{14}$ Another of these is the Gigantomachy, ${ }^{15}$ which may be seen on the fragments of a stamnos. ${ }^{16}$ This subject was particularly topical at the time of the Persian Wars, when the Greeks had to defend themselves against a superior foreign power, just like the gods had once fought their subversive antagonists. Vases of the 6th century ${ }^{17}$ (as well as the Oltos cups mentioned in Chapter 2$)^{18}$ already show Dionysos taking part in the battle. In the case of this stamnos his companions are Apollo and Ares. In this way, Dionysos helps to confirm the order of Zeus - the prevalent order for the original beholders of the vases. ${ }^{19} \mathrm{~A}$ snake

\footnotetext{
Louvre G 162: Addenda 187 (186.47); BA 201699; Huber 1992, 64.

Isler-Kerényi 2004a, 48-50.

Isler-Kerényi 2004a, 19-21.

Louvre G 57: Addenda 188 (188.65); BA 201715.

Hedreen 1992, 112, pl. 35 .

Natale 2008, 73-106.

Lissarrague 2013, 175-189.

Louvre C 10748: Addenda 188 (187.55); BA 201707.

LIMC IV, Gigantes 171, and 175 as well as 289 .

See above Chapter 2 , note 83 .

19 Compare the Gigantomachy on the cup of the Painter of the Paris Gigantomachy, Cab. Méd. 573 (Addenda 234 [417.1]; BA 204546). Here we have on the outer side the Gigantomachy of Poseidon and Hephaistos. A striding, bearded Dionysos between Apollo
} 
serves as his weapon. ${ }^{20}$ In view of his later iconography, it is significant that he is naked except for the chlamys he wears on his shoulders.

In short, as far as the subject matter and the role of the participants in the thiasos are concerned, the Dionysiac imagery of the leading vase painters of the early $5^{\text {th }}$ century does not differ fundamentally from that of the blackfigure phase. From the fact that we find so many inventive, high-quality representations, we may conclude that the interest in this kind of imagery was undiminished. The figure of the satyr, however, is clearly more popular than before; on several amphorae a single satyr dominates the whole of one side. We came across the earliest examples of this in the work of Euphronios, Smikros, and Euthymides. ${ }^{21} \mathrm{~A}$ Panathenaic-type amphora by the Kleophrades Painter is very comparable. ${ }^{22}$ On the one side we see a satyr in counterpose with a barbitos; on the other a young man with a sprouting beard seems to be waiting, leaning on a stick. He carries a hare, which may be a reference to a budding love affair. Does the lover identify himself with the musical satyr (Figure 18)? Perhaps the same idea of a change of role from citizen to satyr is hinted at with a neck-amphora by the Kleophrades Painter. ${ }^{23}$ On the one side we see two athletes with sporting implements standing side by side, on the other two satyrs with wine containers are hurrying towards a symposium. And, as is evident from an amphora with twisted handles, both satyrs and citizens could go to war. The amphora shows on the one side a satyr with shield and spear walking towards the right, on the other a satyr holding shin guards and a helmet (Figure 19). ${ }^{24}$

A satyr with a noble appearance who takes up the whole side of a vase also features in the work of the Berlin Painter, the Kleophrades Painter's best-know contemporary, who was active until well after $470 \mathrm{BC}$. The most famous version, and rightly so, may be found on the splendid amphora, which gave the

and Ares dominates the other side. He wears a long robe. He entangles his adversary (whose shield, significantly, carries a kantharos as its emblem) in branches of ivy.

20 Like, for instance, on a kantharos by the Amphitrite Painter of the next generation, Boston 98.932: BA 205038.

21 See above Chapter 2, notes 51,63 , and 66.

22 Leiden PC 80: Addenda 186 (183.7); BA 20166o. For the correct designation of the instrument, see above Chapter 2, note 48 .

23 St. Petersburg B 1550 (6o9): Para 510 (184.19); вA 201672.

24 Harrow 55: Addenda 187 (183.11); BA 201664; Lissarrague 2013, 180 ff., fig. 153. A satyr wearing a helmet, who puts on his shin guards in the presence of a woman carrying a thyrsos, may be found on a somewhat younger pelike by the Deepdene Painter, London E 377: Para 381 (501.35); вА 205622. 


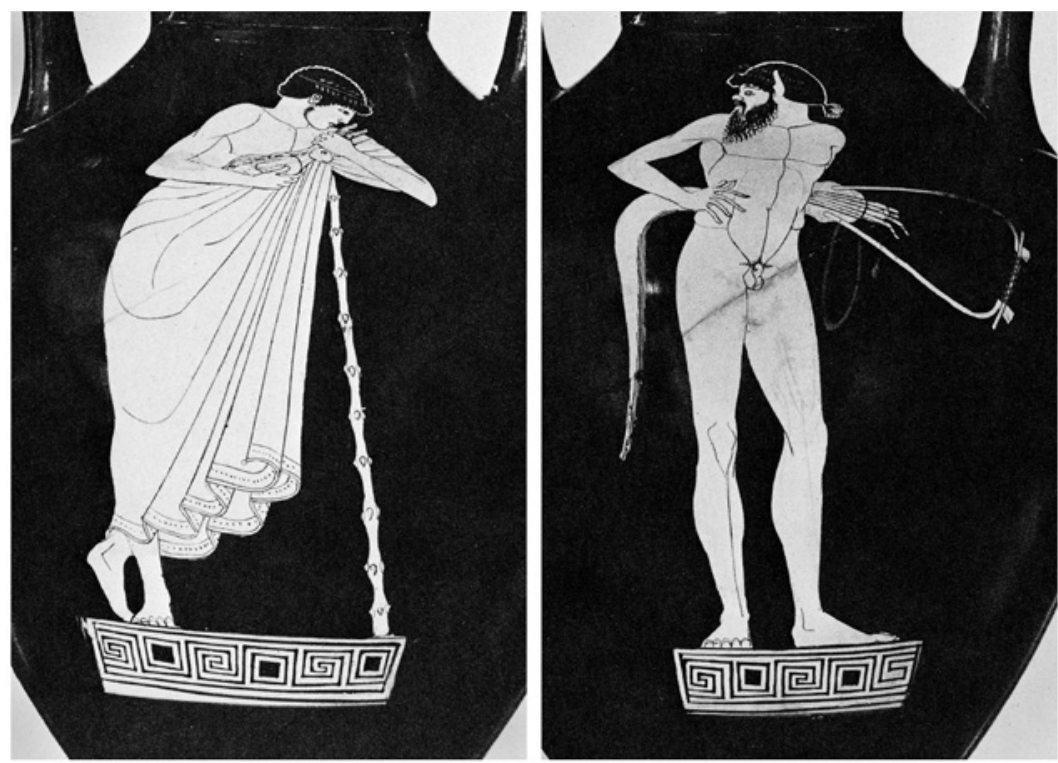

FIGURE 18 Panathenaic-type amphora, Kleophrades Painter, Leiden, Rijksmuseum van Oudheden PC 8o. Photograph (C) RMO.NL (cVA Leiden 3, pl. 120).

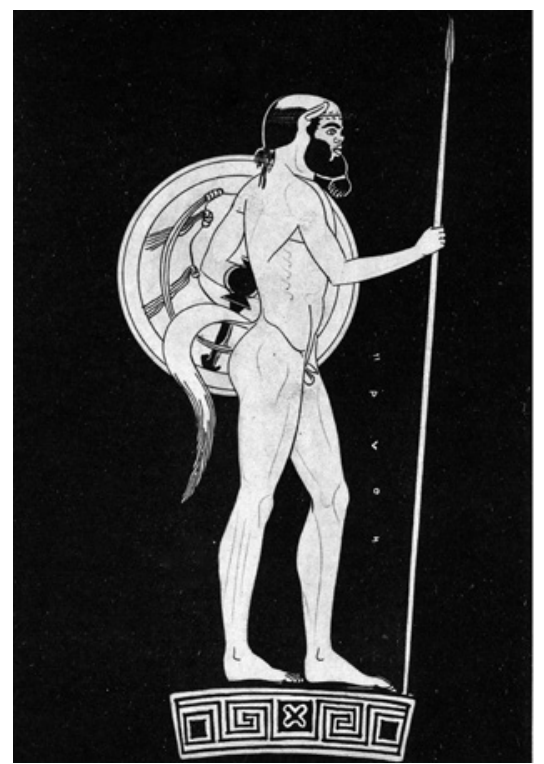

$a$

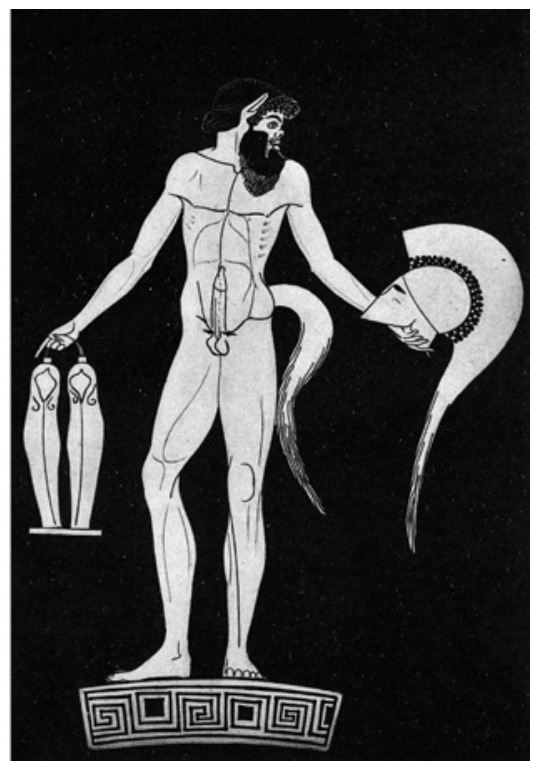

$b$

FIGURE 19 Amphora with twisted handles, Kleophrades Painter, Harrow, School Museum 55.

a. side A (Beazley 1933, pl. 29, 1).

b. side B (Beazley 1933, pl. 29, 2). 
painter his name. ${ }^{25}$ On the one side we find a pensive satyr moving to the right with a barbitos in his left hand and a kantharos in his right. His name is Orochares ('he who rejoices on the mountain'). The reverse shows a satyr by the name of Oreimachos ('he who fights on the mountain') who seems about to play the barbitos. Next to the satyr, and partly obscured by him, Hermes with his kerykeion and a kantharos in his left hand and a libation oinochoe in the other, moves energetically to the right as if to overtake the satyr, who seems to tarry. Between the two, we see a fawn gracefully lifting its head (Figure 20). Without any doubt, the artist also had aesthetic reasons for placing the two figures so very closely together; one look at the amphora as a whole makes this abundantly clear. The precision and elegance of the image are unsurpassed.

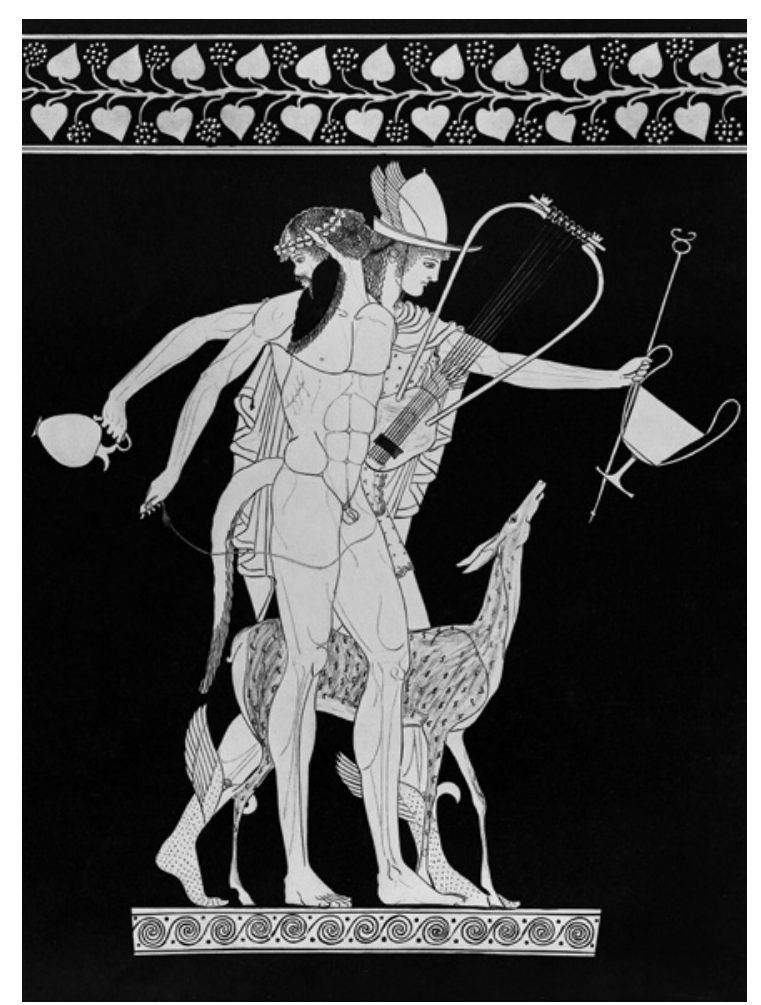

FIGURE 20 Belly-amphora, Berlin Painter, Berlin, Staatliche Museen, Preussischer Kulturbesitz F 2160, side A (FR pl. 159.2).

25 Berlin F 2160: Addenda 190 (196.1); BA 201809; Moore 2006, 17 f.; Lissarrague 2013, 233 f., fig. 203. For the instrument, see above Chapter 2, note 48 . 
Yet, to us it seems enigmatic. What is Hermes doing here? Does he mean to take the satyr to Dionysos, who is evoked by the two kantharoi and the delicate ivy branches on the neck of the vase? The satyr may, however, be more than a being from mythical times; perhaps he also represents a state that may be realized by every citizen entering the sphere of Dionysos. ${ }^{26}$ In that case, the presence of Hermes, the conductor of souls, is perfectly understandable.

The Berlin Painter presented the satyr with the barbitos again and again. We also find him, for instance, on one of his Panathenaic-type amphorae (Figure 21). ${ }^{27} \mathrm{~A}$ rather badly preserved calyx krater shows that in this role he is close to Dionysos himself. ${ }^{28}$ On a bell krater he is awaiting Herakles as a merry symposiast, with his barbitos and an oinochoe. ${ }^{29}$ But the Berlin Painter not only gave the satyr noble features, he also presented him as a comical character. On a small amphora, for instance, we see him flaunting his belly in the manner of the padded dancers of the archaic era (Figure 22). ${ }^{30}$ The latter are, incidentally, closely related to the satyrs. ${ }^{31}$ But why are these two satyrs holding a drinking horn? Is this a reference to primeval times, when drinking utensils were not manufactured but provided by nature?32 From the satyr play we know that satyrs already existed in heroic times, in the era that preceded, indeed prepared, the present. ${ }^{33}$

Among the Berlin Painters finest works are several stamnoi featuring Dionysos. The most original version shows him as a symposiast lying on a goat; Oltos had already similarly depicted him lying on a mule. ${ }^{34}$ On the other side, as a parallel, we see Hermes lying on a ram. He holds the kantharos and the kerykeion in his left hand, and with the right he seems to be beating time for the music-making satyr who is next in the procession. ${ }^{35}$ Another stamnos

26 See the Introduction, page 5, note 15. The hypothesis in Moore 2006, 25 f. that the Berlin Painter alludes to the fact that (on the basis of much later sources) Hermes is often said to be the father of the satyrs, does not accord with the bearded satyr and the youthful Hermes. Nevertheless, playful, exuberant satyrs do sometimes resemble Hermes.

27 Munich 2311: Addenda 190 (197.9); BA 201817.

28 Syracuse 15205: ARV 205.121; BA 201930.

29 Louvre G 174 and Florence 12 B 105: ARV 205.123; BA 201932.

$30 \quad$ New York 07.286.69: Addenda 192 (201.70); BA 201878.

31 Isler-Kerényi 2004a, 33.

32 Isler-Kerényi 2004a, $55 \mathrm{f}$.

33 Brelich 1985, 70: "I miti ... narrano di un passato tutto diverso dal presente, di un tempo in cui accadevano cose che ora non accadono più ..., ma in cui sono state gettate le fondamenta dell'esistenza reale della società che li ricorda".

34 Orvieto, Museo Civico 1049: ARv 64.103; BA 200539. Compare above Chapter 2, note 85.

35 Louvre CA 944: ARV 207.142; BA 201961. 


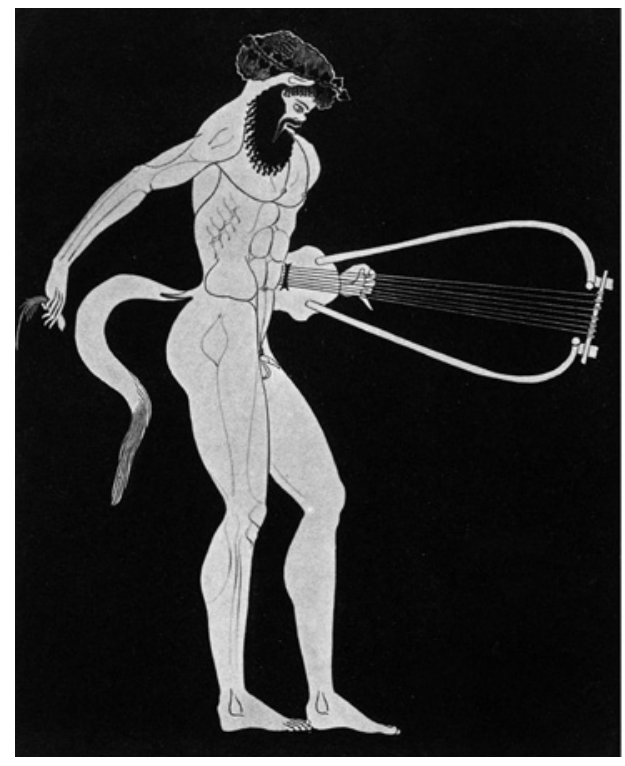

$a$

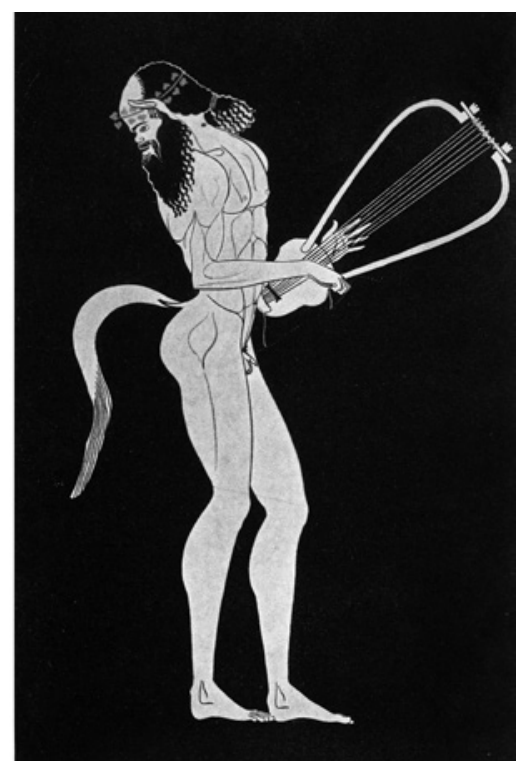

$b$

FIGURE 21 Panathenaic-type amphora, Berlin Painter, Munich, Staatliche Antikensammlungen und Glyptothek 2311.

a. side A (Beazley 193o, pl. 6).

b. side B (Beazley 1930, pl. 6).
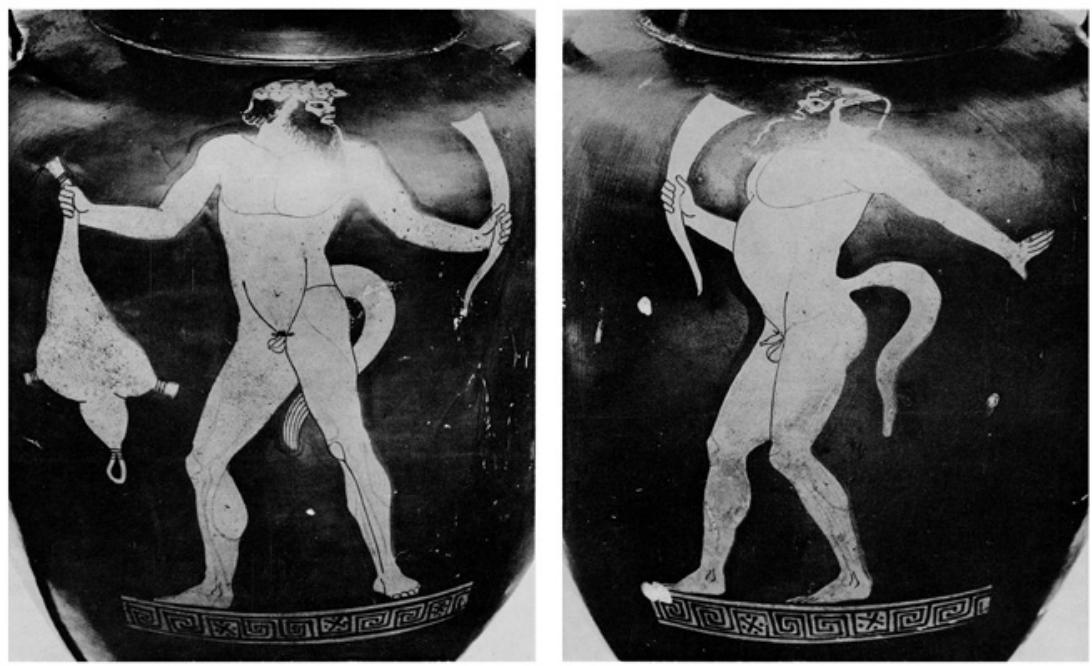

FIGURE 22 Neck-amphora, Berlin Painter, New York, Metropolitan Museum of Art 07.286.69 (Richter 1936, pl. 18). 
shows a version that is more like the familiar thiasos. It has, however, two peculiarities: one of the maenads has a small panther on her arm, and Dionysos carries a gnarled stick instead of a thyrsos (Figure 23). ${ }^{36}$

A fragment of a volute krater by the Berlin Painter shows a bearded figure in a short chiton and a panther skin, whose hand reaches out to Dionysos hastening towards the right. He may be Hephaistos, but this is unclear. ${ }^{37}$ In addition to the motif of Hephaistos riding a mule, which goes back to the 6th century, the early 5 th century sees the emergence of a new motif, that of the two gods walking together, supporting each other, which, in any case, shows them in a much more intimate relationship than the one we find here. ${ }^{38}$ This motif

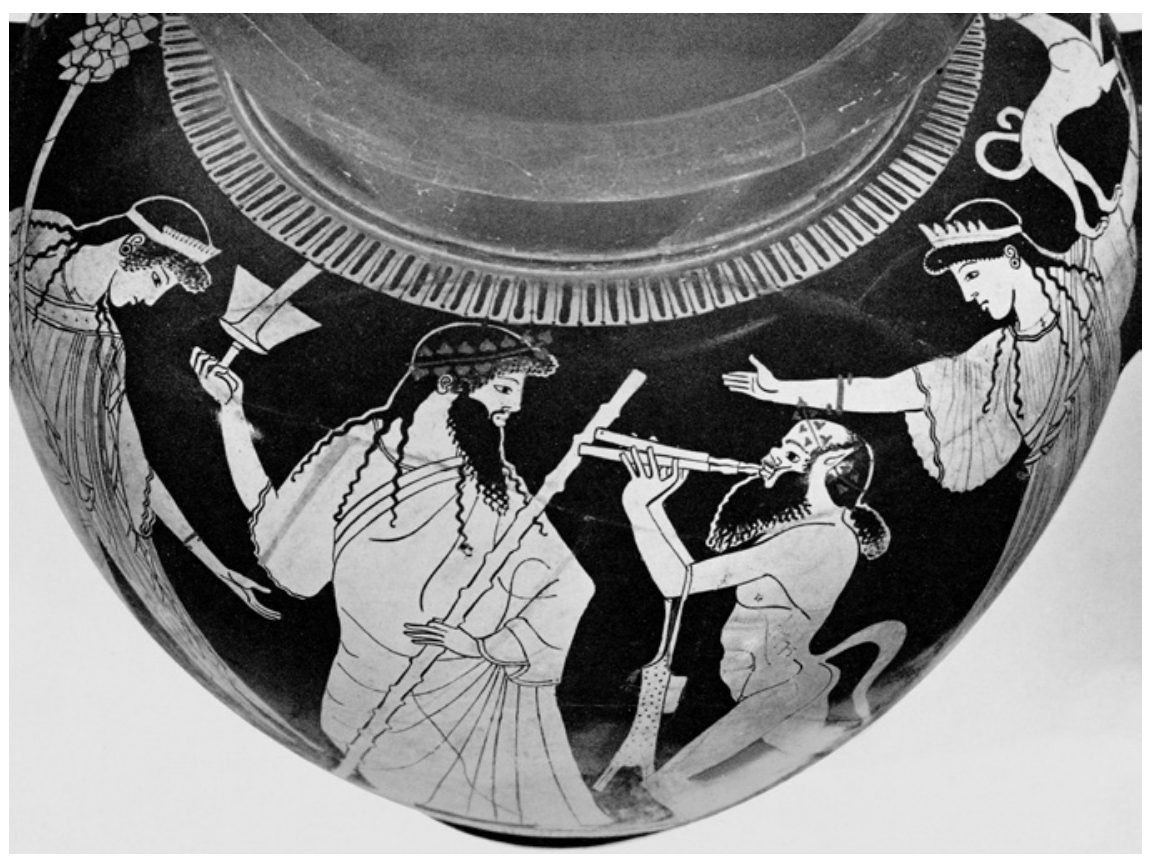

FIgure 23 Stamnos, Berlin Painter, formerly Castle Ashby 72 (cva Castle Ashby pl. 48.3).

36 Formerly Castle Ashby: Addenda 194 (208.145); BA 201964.

37 Vatican AST 703: Addenda 194 (1634.132 bis); BA 275092.

38 Fragments of a krater, Adria B 515 and B 1412: ARV 242.81; BA 202432 (Myson); probably also on an amphora, whereabouts unknown: Addenda 202 (246 below); вA 202463 (perhaps by the Painter of the Munich Amphora, no image); column krater, Tarquinia 683: Addenda 210 (290.7); BA 202639 (Tyszkiewicz Painter). For this new motif: Halm-Tisserant 1986, 8 f.; Schöne 1987, 44; Natale 2008, 102 f. 
underlines the sense of solidarity between these two little-loved scions of the Olympic family. It is conceivable, that the novelty was inspired by a satyr play, ${ }^{39}$ and that a discussion about the status of the nothoi (the unlegitimized sons of Athenian citizens) formed the background to the use of this motif in both the performing and the visual arts. ${ }^{40}$

The solidarity with Hephaistos brings us to the question of how the Berlin Painter treats the relationship between Dionysos and the other gods. The assembly of the gods on one of his stamnoi is hard to interpret. ${ }^{41}$ We see Apollo with his kithara who is hailed by Zeus in the presence of two female figures. On the left, he is followed by Nike or Iris. The scene is continued on the other side of the vase where we see Dionysos and Hermes walking towards the right, i.e. likewise towards the Olympus. Between them is a woman holding aloft two torches. The young Apollo with his kithara is also the protagonist of one of the sides of a sumptuous, but fragmentary calyx krater by the Berlin Painter. ${ }^{42}$ He stands between two youthful women, probably Muses rather than Artemis and Leto. ${ }^{43}$ To the left of this group, a bearded Dionysos moves in the opposite direction. On the other side of the vase we see Athena and her quadriga, hailed by Zeus and Hermes.

These are two artistically outstanding but rather enigmatic works. The only thing that may be deduced from them with any certainty is Dionysos' connection with the family of Olympian gods and his special relationship with the two other sons of Zeus, Apollo and Hermes. A magnificent dinos by the Berlin Painter offers further information about his role in this context (Figure 24). ${ }^{44}$ This exclusive vessel for mixing wine, a rarity in Greek ceramic art, presents him and other gods taking leave of Zeus who is about to depart from the Olympus. ${ }^{45}$ Zeus is shown with Athena, Hermes, Apollo with his kithara, Poseidon with fish and trident, and Amphitrite. To the left of Zeus, Dionysos follows Nike. With lips parted, which indicates he is speaking, he turns towards a goddess carrying a scepter, and an anonymous male figure, possibly a mortal. Dionysos is the only one among the gods to directly address this man. We do not know

39 Buitron-Oliver 1995, $39 \mathrm{f}$. In support of this see the calyx krater, Vienna 985 by the Altamura Painter (Addenda 264 [591.20]; BA 206838), where the two brothers are preceded by a satyr in a phallus costume: Natale 2008,103 , fig. 31 and here 91 fig. 45 .

Compare Isler-Kerényi 2007, $90 \mathrm{f}$.

41 London E 444: ARV 208.149; BA 201968.

42 Athens, Acr. 2.742 and London E 459: Addenda 193 (205.117); BA 201926 (no image).

43 See Lullies 1971, 53.

44 Basel Lu 39: BA 308 (no image); Lullies 1971, 44-55; Isler-Kerényi 2008a, 78 and fig. 8.

45 Kästner 2008a, $62 \mathrm{f}$. 


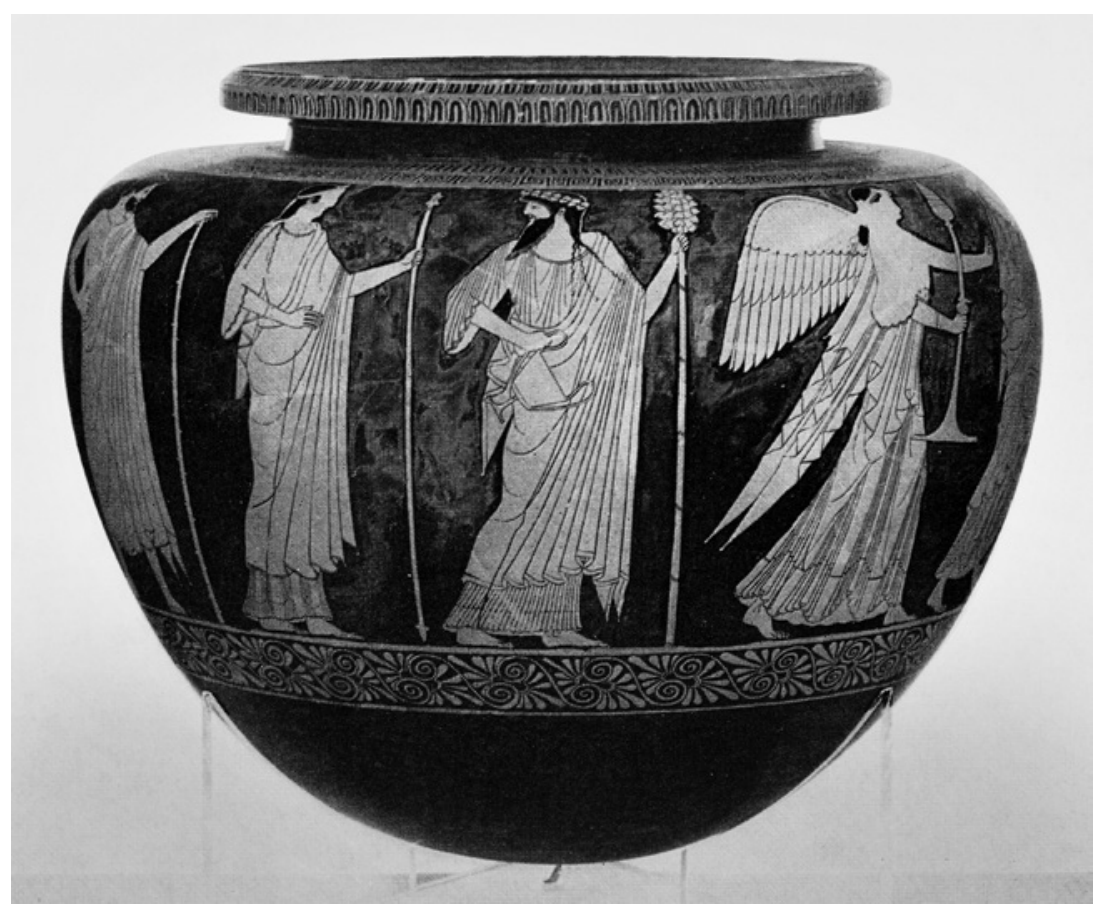

$a$
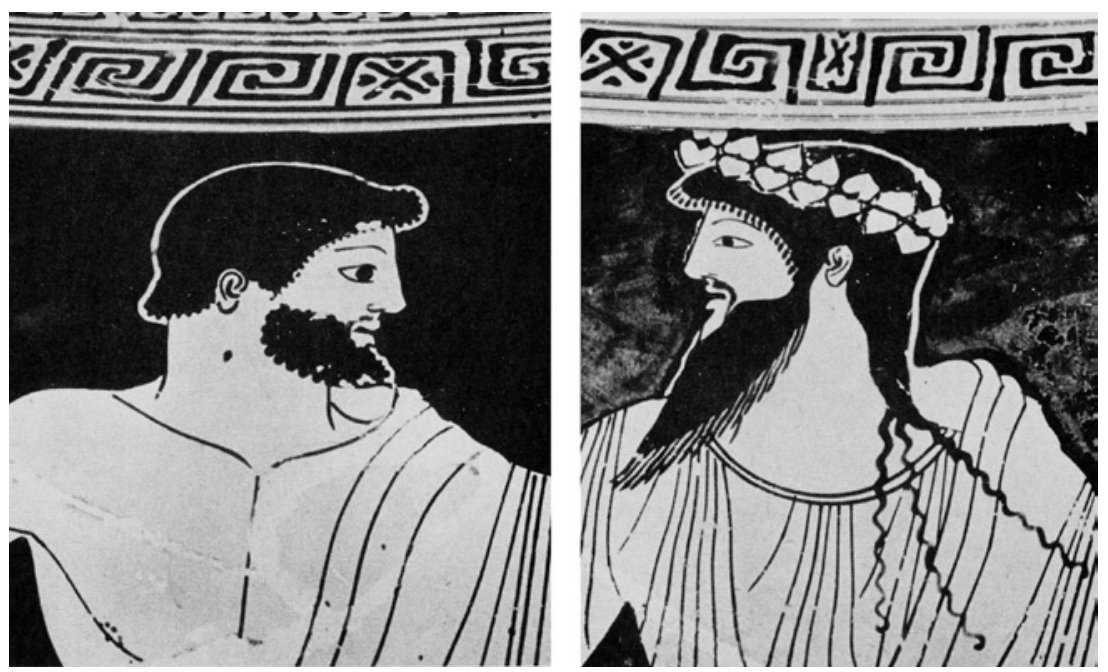

$b$

FIGU Re 24 Dinos, Berlin Painter, Basel, Antikenmuseum Basel und Sammlung Ludwig Lu 39. a. view of the vase with Dionysos (Lullies 1979, 1116).

b. detail: head, probably of Peleus, and head of Dionysos (Lullies 1971, pl. 19.2-3). 
the mythological context of this particular leave-taking scene, but because it is Dionysos who speaks to the man and his divine companion, we may presume the anonymous mortal is Peleus and the occasion, therefore, is the marriage of Peleus and Thetis. This would correspond with the role given to Dionysos on a dinos by Sophilos a hundred years earlier. ${ }^{46}$ It was Dionysos who, as the only one among the gods, directly addressed Peleus at his marriage to a goddess. The mortal hero Achilles, one of the protagonists of the Trojan War, was born from this marriage, all of which in the end served to confirm the order of Zeus. A somewhat younger pointed amphora by Syriskos, discussed below, proves that in the $5^{\text {th }}$ century one was still aware of Dionysos' role as a mediator in situations which threatened the legitimate world order. ${ }^{47}$

On two of his kalpides, the Syleus Painter, another of this generation of painters of large-size vases, has depicted elements from Dionysiac mythology that are not often seen in vase painting: we see Ariadne who is led away by the god while Theseus is sent away by Athena, ${ }^{48}$ and Zeus leaving the child Dionysos in the care of the nymphs. ${ }^{49}$ We will come back to these motifs in the context of comparable younger representations. ${ }^{50}$

Among the lesser painters of this time, we find Myson, the Harrow Painter, and the Flying-Angel Painter, who all seem to have favored column katers, as well as the Geras Painter, who preferred pelikai. It is remarkable that, apart from Dionysos, mythological figures hardly feature in their work. In addition, their repertoire is dominated by anonymous youths and men, and by athletes and warriors. The main protagonist in the work of these less eminent, but nevertheless often original artists, is the satyr. We have earlier seen him as the alter ego of the symposiast, in the role of the musician and the carrier of wine sacks, mixing vessels and pitchers. Now he is also depicted as an athlete, almost indistinguishable from a normal human one. ${ }^{51}$ We also see him as Hermes' assistant in a ludicrous scene, making a goat dance to the music of his flute. ${ }^{52} \mathrm{He}$ can play with other satyrs in a childlike manner, or lug about an enormous

\footnotetext{
46 Isler-Kerényi 2007, 75 .

47 See below Chapter 4, note 47.

48 Berlin F 2179: Addenda 203 (252.52); BA 202898.

49 Cab. Méd. 440: Addenda 203 (252.51); BA 202896.

50 See below Chapter 5 .

51 Munich 2381: Addenda 198 (221.14); BA 202099 (Nikoxenos Painter), and New York 12.229.13: ARV 276.80; BA 202679 (Harrow Painter).

52 Samothrake 57.565: ARV 232.1; Para 174.23bis; BA 202274 (Eucharides Painter, black-figure).
} 
artificial phallus. ${ }^{53} \mathrm{He}$ can play pranks in front of a statue of Dionysos. ${ }^{54} \mathrm{He}$ can approach the god in a comical costume. ${ }^{55} \mathrm{He}$ can be scolded by Dionysos. ${ }^{56}$ Just like normal people, he can get water from a spring, ${ }^{57}$ cook a meal, ${ }^{58}$ draw water from the public well. ${ }^{59} \mathrm{He}$ makes us laugh when he mimes a respectable citizen ${ }^{60}$ or eats stolen grapes. ${ }^{61}$ It is hardly a coincidence that the majority of these images were created by the Geras Painter. He favored the pelike, a vase type that must have been predestined to carry unconventional representations. ${ }^{62}$ But how should we explain the fact that, apparently, satyrs could damage gravestones or herms (Figure 25), ${ }^{63}$ or molest or even threaten women carrying out rituals? ${ }^{64}$ Would this not also be sacrilege for satyrs?

\section{Painters of Cups}

The ascendancy of anonymous figures over mythological ones is even more evident in the work of the cup painters of the period between 500 and about 470 вс. ${ }^{65}$ Their output was often very large: Beazley attributed more than 170 items to Onesimos and his circle, over 220 to the Brygos Painter, over 310 to Douris, and more than 350 to Makron. Almost all of these are cups. However,

53 Boston 98.882: Addenda 208 (279.7); BA 202711 (Flying-Angel Painter) and Copenhagen, Thorvaldsen Museum 99: Addenda 209 (287.24); BA 202595 (Geras Painter).

54 Louvre G 227: Addenda 208 (283.2); BA 202563 (Painter of Louvre G 238).

55 Boston 64.2032: Addenda 209 (285.2); BA 202577 (Geras Painter).

56 Leipzig T 643: Addenda 209 (286.9); BA 202584 (Geras Painter).

57 Harvard 1925.30.34: ARV 285.7; BA 202582 (Geras Painter).

58 Berkeley 8.4583: Addenda 209 (286.10); BA 202585 (Geras Painter).

59 Berlin F 2173: Addenda 209 (286.18); BA 202589 (Geras Painter).

6o Oxford 283: ARV 286.21; BA 202592 (Geras Painter); Lissarrague 2013, 200, fig. 170 (Geras Painter). Satyr-citizens occur in red-figure vases from about 480 вС onwards: Lissarrague 2013, 204. Concerning the black-figure version, see Lissarrague 2013, 291, Annexe 26.

61 Oxford 1922.67: ARV 312.1; BA 203213 (Class of Vienna 3717).

62 Shapiro 1997; Schöne-Denkinger 2014, $13 \mathrm{f}$.

63 Louvre CA 1947: Addenda 201 (240.44); BA 202393 (Myson) and Florence v 5: Addenda 208 (281.34); BA 202540 (Flying-Angel Painter), likewise Lausanne 3250: Para 355 center; BA 352524 (no image) (Geras Painter); Bérard 1966. In Bérard/Bron 1986 he himself refuted his earlier interpretation, current at the time, of satyrs as a kind of fertility demon; Lissarrague 2013, $201 \mathrm{ff}$., figs 173-174.

64 For instance Oxford 307: ARV 393.37; BA 204235 (Painter of Munich 2676). For a similar situation, a satyr pursuing a woman who holds a torch, see Louvre G 202: ARV 226.4; BA 202223 (Eucharides Painter).

65 Compare Kästner 2008a, 64 f. and 69 . 


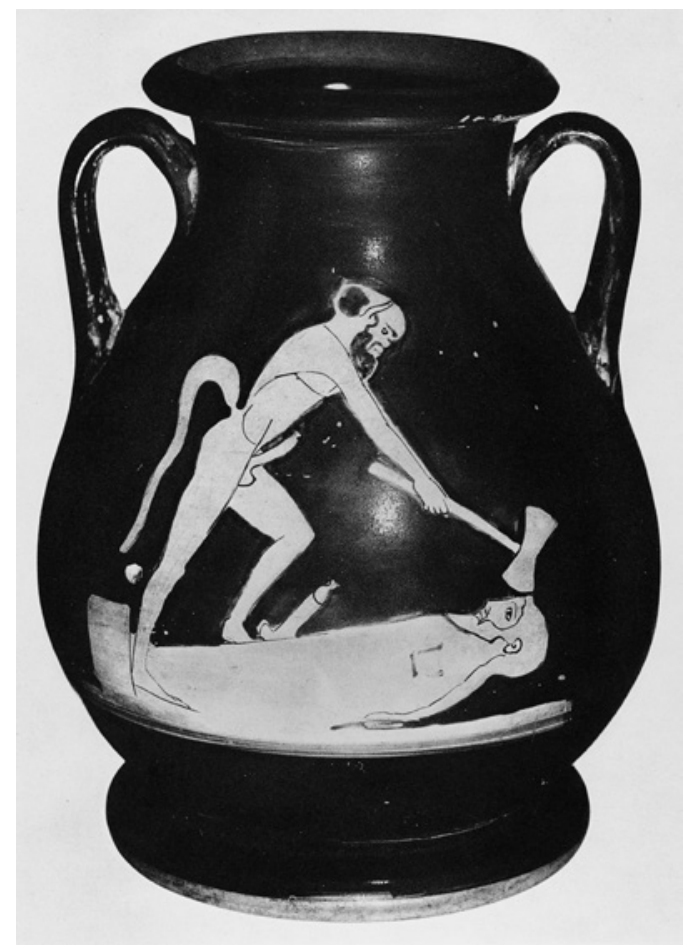

FIgURE 25 Pelike, Geras Painter, Lausanne, (C) Musée cantonal d'archéologie et d'histoire INV 325o, side A (Bérard 1966, 95, pl. 21).

Dionysos and his thiasos are depicted rather infrequently; komos and symposium are better represented.

Let us first look at Onesimos, who was active between c. 510 and c. 480 BC and whose signed cup was produced by the potter Euphronios. ${ }^{66} \mathrm{He}$ was mainly interested in athletes and horses; his favorite mythological figures were, appropriately, Athena and Herakles. Among Dionysiac subjects, he favored komos and symposium, followed by satyrs. His best known satyr is found on a cup of which only the medallion is decorated. This aged, ithyphallic satyr is sitting rather unstably on a transport-type amphora in a typical attitude of 'indecent exposure' (Figure 26). ${ }^{67}$

The Brygos Painter, a skillful and original artist, seems to have had more affinity with Dionysiac subject matter. Apart from a few small vases, he mostly

\footnotetext{
66 Boardman 1975, 133.

67 Boston 10.179: ARV 327.110; BA 203364.
} 


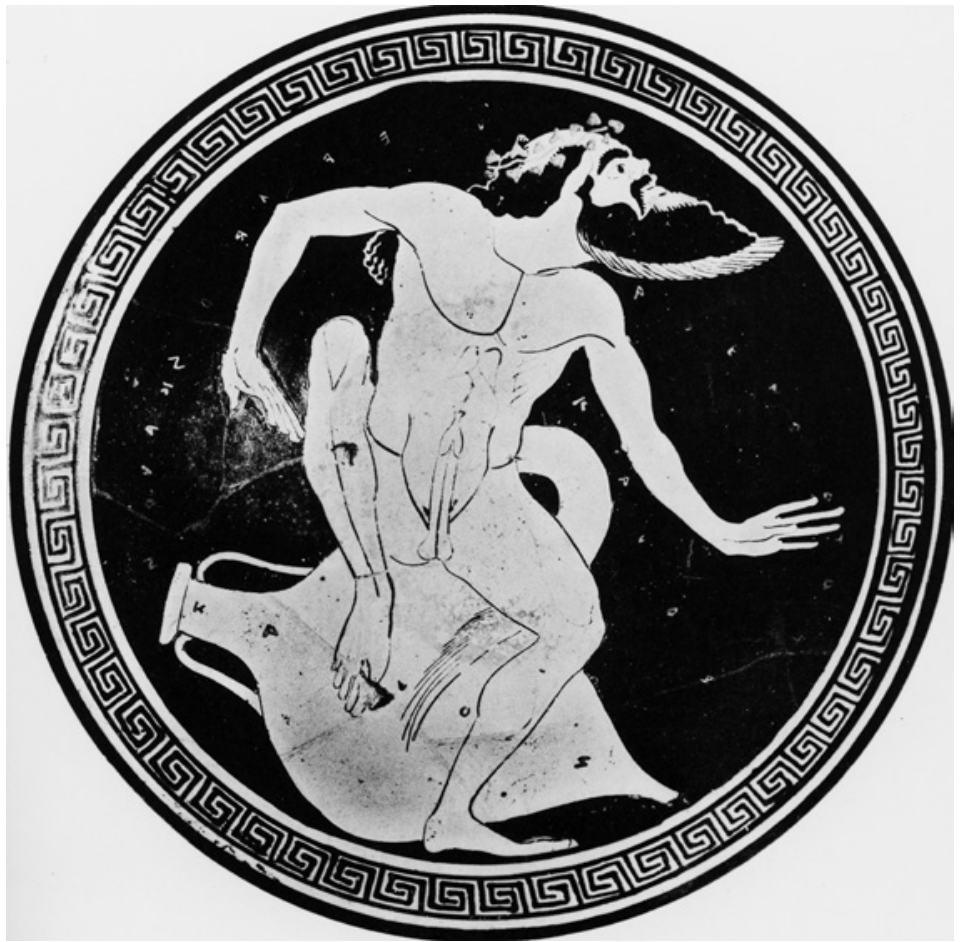

FIGURE 26 Cup, Onesimos, Boston, Museum of Fine Arts 10.179 (Langlotz 1922, pl. 8).

painted cups. His activities began after 490 BC and continued beyond $470 .^{68}$ Here, too, anonymous figures dominate. Besides athletes and warriors, however, we also quite often find komos and symposium as well as satyrs and maenads. His thiasoi are rather poetic and music is given an important role: even Dionysos himself may appear on the scene as an ecstatic barbitos player. ${ }^{69}$ One thiasos cup deserves special mention because of its high quality: its tondo shows, on a white ground, a maenad wearing a snake diadem, who brandishes a small panther (Figure 27). The effect is both graceful and uncanny. ${ }^{70}$ Even though figures are rarely seen on this vase in the shape of a drinking horn, the Brygos Painter also decorated several rhyta. ${ }^{71}$ The one that is best known shows, on both sides of the body, a satyr welcoming Dionysos with the music

68 Boardman 1975, 135.

69 For instance Cab. Méd. 576: Addenda 225 (371.14); BA 203913.

$70 \quad$ Munich 2645: Addenda 225 (371.15); BA 203914.

71 ARV 382 f., 185-195. For this type of vase: Hoffmann 2007, 161-205, especially 165. 


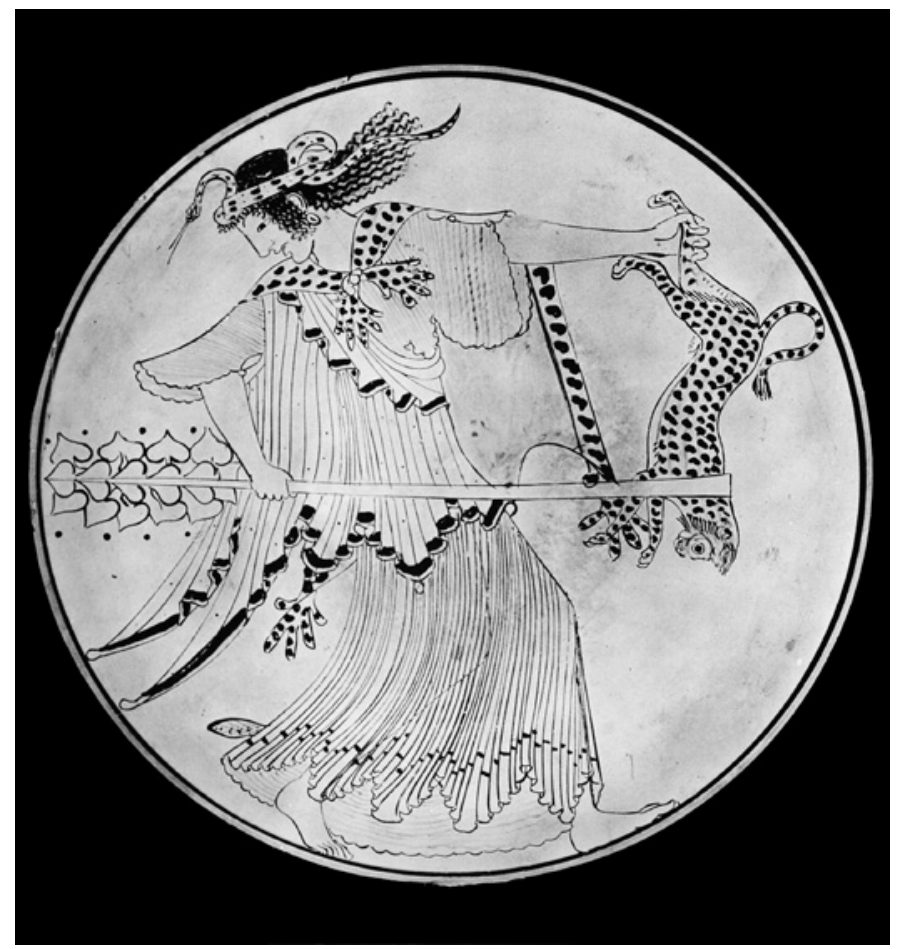

FIGURE 27 Cup, Brygos Painter, Munich, Staatliche Antikensammlungen und Glyptothek, 2645, tondo image on a white ground (FR pl. 49.1).

of the aulos at an altar decorated with ivy. ${ }^{72}$ On both sides of the opening a satyr is stealing on a sleeping maenad. The motif of lecherous satyrs surprising maenads in their sleep can already be found on a kalpis by the Kleophrades Painter (Figure 28). ${ }^{73}$ However, it appears more often on cups than on other vase types. ${ }^{74}$ The motif refers to the subversive nature of satyrs. Its mythological counterpart is the assault made by satyrs on Hera and Iris depicted on another of the Brygos Painter's cups. This motif may have been inspired by

72 Warsaw, ex Goluchow 119: Addenda 228 (382.185); вА 204084.

73 Rouen 583.3: Addenda 188 (188.68); BA 201716.

74 For instance: Baltimore without number: Addenda 215 (320.10); вА 203260 (Onesimos); Louvre S 1339, S 1328: ARV 320.11; BA 203261 (Onesimos); Boston (Onesimos); Boston 01.8072: Addenda 244 (461.36); BA 204718 (Makron) and, of a later date, Louvre G 206: ARV 530.22; BA 205998 (neck-amphora by the Alkimachos Painter). For this motif, see McNally 1985, 157 f.; Paul-Zinserling 1994, 53 f.; Lindblom 2011, 38-45; Lissarrague 2013, 89 f. 


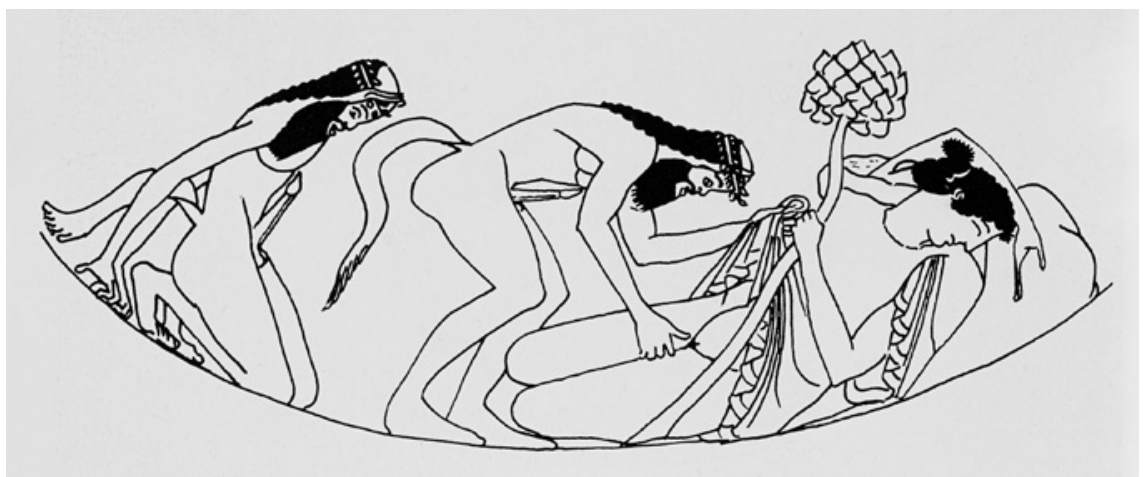

FI U RE 28 Kalpis, Kleophrades Painter, Rouen, Musée Départemental des Antiquités 583.3 (Lissarrague 1987, 88, fig. 22).

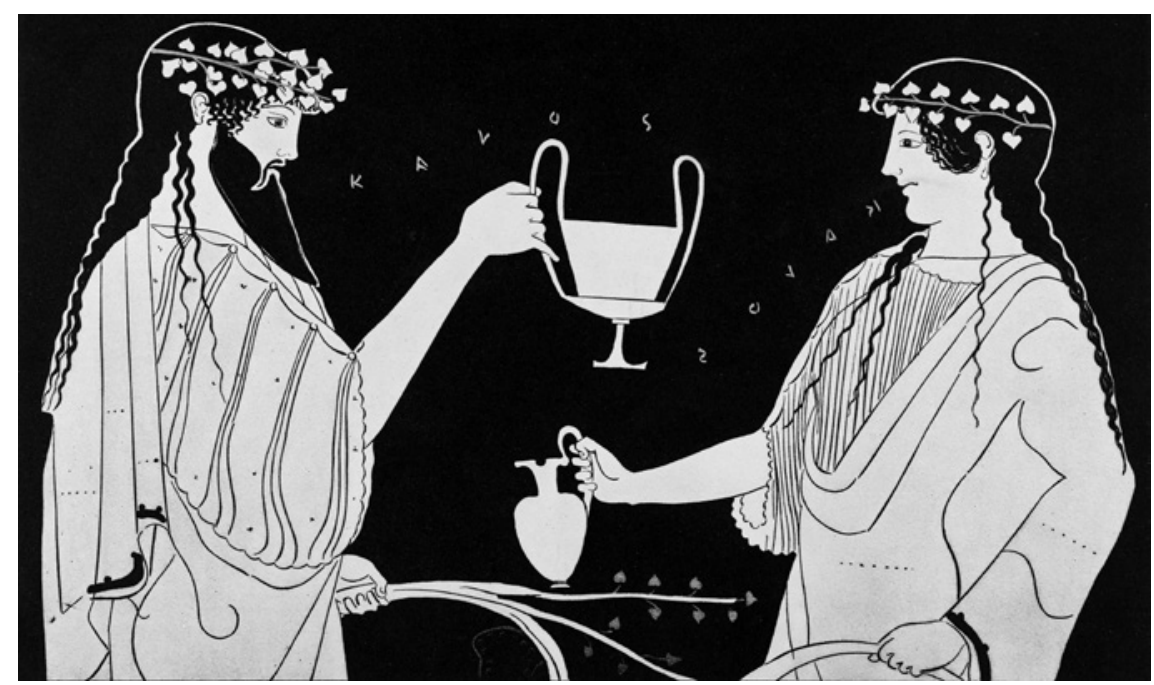

FI U URE 29 Kalathos, Brygos Painter, Munich, Staatliche Antikensammlungen und Glyptothek, 2416, detail of side B (FR pl. 64 below).

a satyr play. ${ }^{75} \mathrm{~A}$ unique, and rightly famous, cooling vessel in the shape of a basket, designated as a kalathos, shows a dignified young woman solemnly approaching Dionysos (Figure 29). On the other side we see the meeting of the poets Alkaios and Sappho. ${ }^{76}$

75 London E 65: Addenda 224 (370.13); BA 203912. In addition Schoenmann/Krumeich in: Krumeich/Pechstein/Seidensticker 1999, $5^{26}$ f., fig. 29; Lissarrague 2013, 47 ff., fig. 22.

76 Munich 2416: Addenda 228 (385.228); BA 204129. 
The Briseis Painter, a minor cup painter from the circle of the Brygos Painter, was mainly interested in the everyday life of women. ${ }^{77}$ Two of his works, however, are exceptional for various reasons. One of his cups not only stands out because its outside shows Dionysos dancing like a maenad, but also because its tondo has an enigmatic encounter between an ephebe and an elderly man in front of the door to a house. ${ }^{78}$ The outside of a cup from Ruvo in Apulia-a site that gains in importance in the late 5 th century-shows quiet scenes with anonymous figures. Its white background tondo is remarkable for its depiction of a satyr with a noble appearance in the manner of the Kleophrades Painter and the Berlin Painter. ${ }^{79}$

One of the most productive painters of this time is Douris. About three hundred vases are attributed to him. Most of them are cups, but he also decorated a number of other small vase types. His activities begin shortly before 500 and continue well beyond $470 \mathrm{BC} .{ }^{80}$ His main theme is the world of men: war, sport, love, komos and symposium. Douris is no different from other painters of cups in that in his work, too, Dionysos and his thiasos occur more frequently than mythological scenes. His version of the return of Hephaistos is, however, remarkable. ${ }^{81}$ Dionysos lovingly leads his half-brother by the hand in a procession headed by a satyr making music and one carrying a heavy bell krater. A dancing nymph accompanies them. Hephaistos has his hammer over his shoulder; a third satyr, carrying the goat skin bellows, brings up the rear (Figure 30). On the other side, youthful and mature komasts dance in pairs to the music of a barbitos player. In the tondo Hera sits on her throne in a dignified manner. She holds a conversation with Zeus who stands before her. Douris in this way underlines the mythologlical context of the episode, while at the same time highlighting the analogy between the human komos and the Dionysiac thiasos. This analogy may also be hinted at in the tondo of another cup where a komast is apparently leading his friend to the symposium. The outside has, on both sides, five bearded komasts dancing solemnly towards the right. $^{82}$

77 Boardman 1975, 137 .

78 London 1843.11-3.54: Addenda 232 (406.2); BA 204401. Compare a stamnos with Dionysos dancing, London E 439: Addenda 211 (298 center); BA 203092 (Hephaisteion Painter).

79 Ruvo 1529A: Addenda 232 (408.33); BA 204431.

80 Buitron-Oliver 1995, 3 .

81 Cab. Méd. 542: Addenda 239 (438.133); вA 205179; Buitron-Oliver 1995, 39 no. 178, pl. 100.

82 London 1843.11-3.4 (E 54): Addenda 238 (436.96); BA 205142; Buitron-Oliver 1995, no. 144, pl. 85 . 


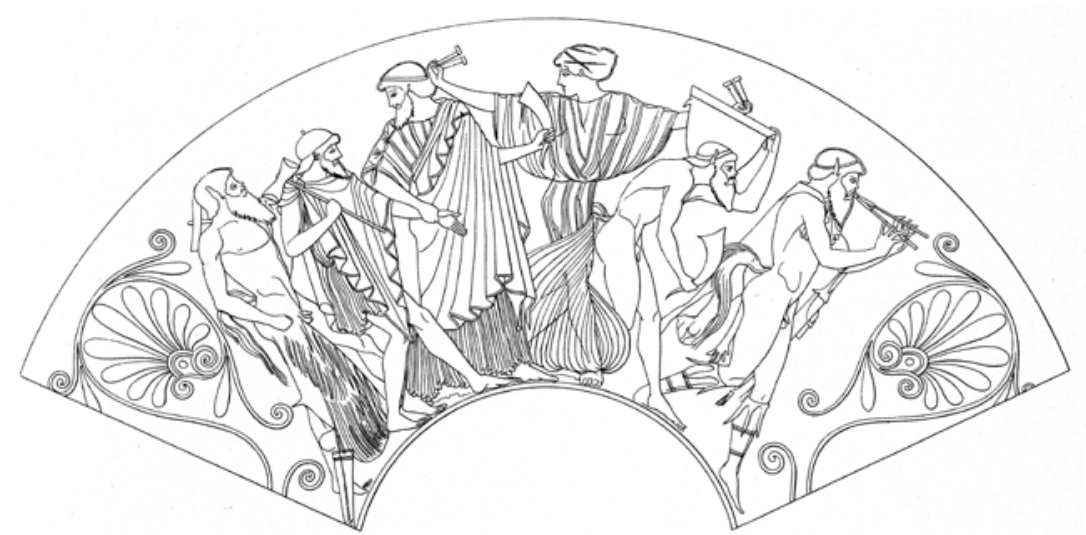

FI GURE 30 Cup, Douris Paris, Bibliothèque Nationale de France, Cabinet des Médailles 542 (Brommer 1978, 15, fig. 6).

The punishment of Pentheus, best-known from Euripides' Bakchai, belongs to the mythology of Dionysos, but is not often depicted. The tondo of one of Douris' cups shows a bacchante with a thyrsos in her left hand, while her right hand holds a leopard by the tail. ${ }^{83}$ On the outside we see two women grabbing hold of Pentheus' arms and head; only his upper body is still intact. Two other women and a satyr are present at the scene. The latter, appalled, looks out of the image at the viewer. The other side shows a Dionysos of gigantic stature sitting on a folding chair with the kantharos and ivy branch in his hands. To the left a satyr is approaching, playing the double flute. A woman on the left side and two on the right are moving energetically, each with a part of Pentheus' body in her hands; the two women near the handles are shown en face, a device for which Douris had, as other images show, a predilection (Figure 31). ${ }^{84}$

The medallion of another of Douris' cups shows Dionysos as a symposiast on one couch with Herakles. ${ }^{85}$ The outside has, on both sides, three youthful pairs of friends in conversation; it is clear that Dionysos and Herakles are their mythical models.

83 Fort Worth AP2000.02: BA 11686 (no image); Buitron-Oliver 1995, no. 121, pl. 73. Lissarrague 2013, 168 f., fig. 144. In the case of the psykter by Euphronios (see above Chapter 2, note 49) it is unclear if and how Dionysos was represented.

84 Buitron-Oliver 1995, 35.

85 Private collection: Buitron-Oliver 1995, no. 185, pl. 103. 


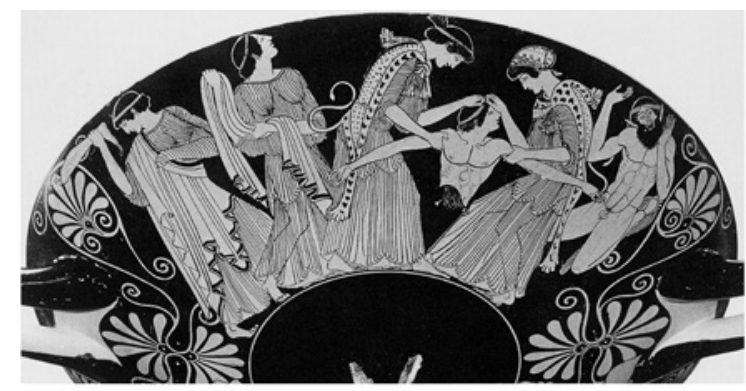

$a$

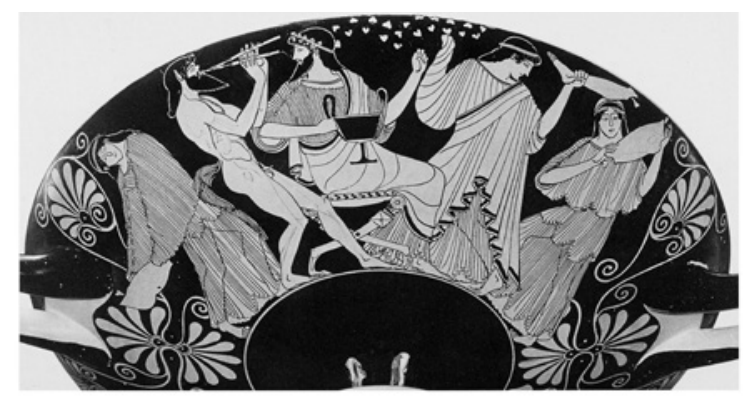

$b$

FIgURE 31 Cup, Douris Fort Worth (Tx), Kimbell Art Museum (AP20oo.o2).

a. Pentheus (Buitron-Oliver 1995, pl. 73).

b. Dionysos (Buitron-Oliver 1995, pl. 73).

We find one of Douris' best-known Dionysiac scenes on a psykter. ${ }^{86}$ Ten satyrs, probably his earliest, are performing various acrobatic tricks with symposium vessels. Another, exotically attired, satyr is apparently delivering a message to them; with his kerykeion he seems to be miming Hermes (Figure 32). A painter from Douris' entourage decorated the outside of a cup with satyrs enjoying themselves in a similarly imaginative manner. ${ }^{87} \mathrm{~A}$ comparable scene on a cup by a painter from the circle of the Nikosthenes Painter is grossly homoerotic. ${ }^{88}$

The Triptolemos Painter was an artist who belonged to Douris' circle. He was active from the 8 os until around 470 BC. He only decorated cups in the early

86 London E 768: Addenda 241 (446.262); BA 205309; Buitron-Oliver 1995, 34, no. 84, pl. 54 f.; Lissarrague 2013, 146 f., figs 122-123.

87 Vatican 16541: Addenda 242 (451.1); BA 205372 (Oedipus Painter).

88 Berlin 1964.4: Addenda 177 (Para 334); BA 275638 (no image); Schlesier/Schwarzmaier 2008, 21, fig. 3 . 


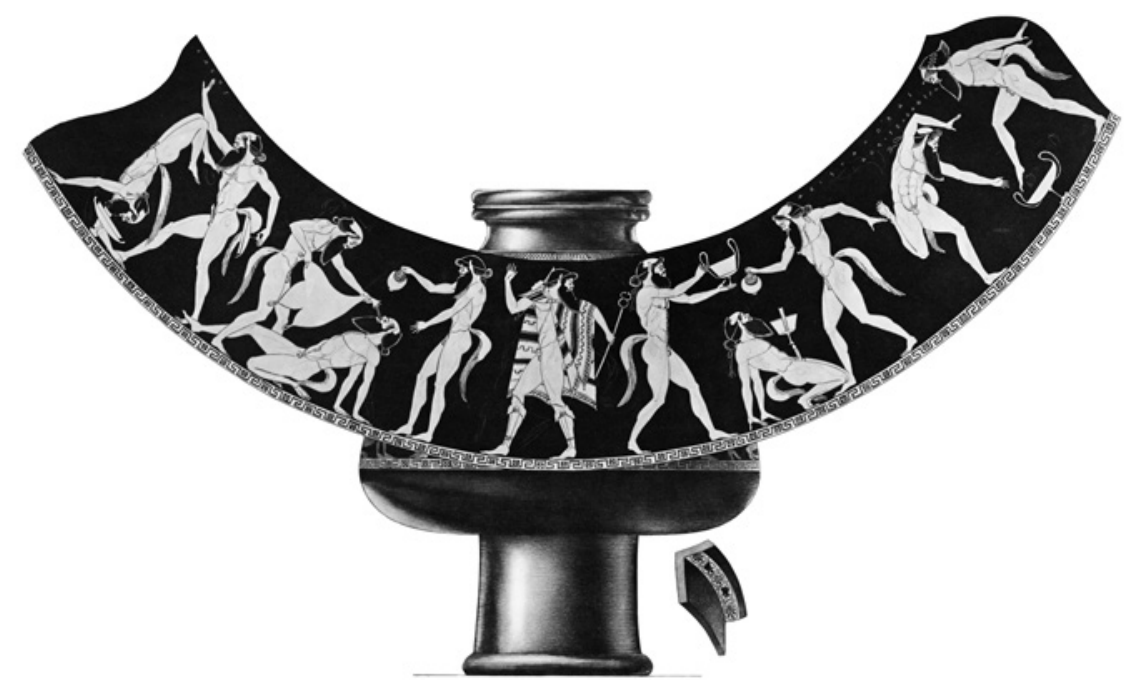

FIGURE 32 Psykter, Douris London, British Museum E 768 (FR pl. 48).

stages of his career, later he also decorated larger vase types, such as stamnoi, column kraters and pelikai. ${ }^{89}$ One of his cups is a good example of a conventional theme depicted in an original manner. ${ }^{90}$ In the tondo a satyr, full of lust, is assaulting a nymph, who seems more surprised than frightened. On the outside in the center Dionysos is walking to the right, but turns towards the maenad nearest to him; the maenad to his right is approaching with an oinochoe. In contrast to the other side, where women are dancing gracefully, the four women on this side are behaving unusually quietly. In this way the painter has managed to merge the thiasos theme and the motif of the encounter-salute, which normally features no more than two figures. Another cup, with a unique depiction of a ritual, will be discussed in one of the following chapters. ${ }^{91}$

In the context of the study of Dionysiac imagery, Makron, whose work may be dated between 490 and $470 \mathrm{BC}$, is the most rewarding among the cup painters of his generation. ${ }^{92}$ Most cups, about 350, are attributed to him. Although anonymous men and youths are also Makron's main subject, he seems to have been more interested in the Dionysiac thiasos than his colleagues. Numerous fragments found on the Acropolis testify to his popularity, not only in Etruria

\footnotetext{
89 Boardman 1975, $139 \mathrm{f}$.

9o Louvre G 250: Addenda 223 (365.58); BA 203850.

91 See below Chapter 6, note 2.

92 Boardman 1975, 140. For the dating see also Isler-Kerényi 1984, 154-156 and Kunisch 1997, $18-21$.
} 
but also in Athens. ${ }^{93}$ Many of his tondi are Dionysiac: we find various scenes depicting the advent of the god or with Dionysos dancing on his own, ${ }^{94} \mathrm{a}$ single satyr ${ }^{95}$ or a satyr with a nymph, mostly in non-aggressive relationships (Figure 33). ${ }^{96}$ We also find maenads, alone ${ }^{97}$ or in pairs. ${ }^{98}$ Single satyrs seem to be rather the exception. ${ }^{99}$ The designs of the innumerable, more or less energetic, thiasoi on the outsides are as varied and inventive as those of the tondi. We find thiasoi with and without Dionysos, sometimes (even though there are maenads in the tondo) with only maenads, ${ }^{100}$ once with only satyrs. ${ }^{101}$ One never has the impression that the artist is unthinkingly using familiar themes, on the contrary: he seems to have done his best to constantly come up with new compositions and gestures. As a rule, the thiasos is supposed to be a circle dance. Occasionally, however, it appears to be a procession moving to the right, in the direction of an unknown destination. ${ }^{102}$ This is a novelty that after 480 B can also be found on other image carriers.

\section{Pala 2012, $217 \mathrm{ff}$. with table fig. 122.}

94 Rome, Villa Giulia 50396: Addenda 245 (465.82); BA 50396; Kunisch 1997, no. 63, pl. 25; Athens, Acr. 2.307: ARV 478.38; BA 204990 (no image); Kunisch 1997, no. 168, pl. 62.

95 Brussels R 247: Para 377 (462.41); BA 204723; Kunisch 1997, no. 103, pl. 38; Boston 13.67: Para 378 (478.309); BA 204991 (no image); Kunisch 1997, no. 197, pl. 68; private collection: Para 377 (462.44); BA 204726 (no image); Kunisch 1997, no. 314, pl. 105; Berlin F 229o: Addenda 244 (462.48); BA 204730; Kunisch 1997, no. 345, pl. 116.

96 Louvre G 144: Addenda 244 (462.43); BA 204725 (no image); Kunisch 1997, no. 98, pl. 37; New York 06.1152: Addenda 245 (463.52); вA 204734 (no image); Kunisch 1997, no. 151, pl. 54; Florence 3943: ARV 478.311; BA 204993; Kunisch 1997, no. 188, pl. 65; Harvard 1972.41: ARV 462.45; BA 204727 (no image); Kunisch 1997, no. 305, pl. 101; Munich 2654: ARV 462.47; BA 204729 (no image); Kunisch 1997, no. 340, pl. 114; New York 20.246: ARV 467.118; BA 204800 (no image); Kunisch 1997, no. 377, pl. 130.

97 Basel Kä 410: Addenda 245 (463.53); BA 204735; Kunisch 1997, no. 128, pl. 44; Louvre G 160: Addenda 247 (478.312); BA 204994 (no image); Kunisch 1997, no. 16o, pl. 57.

98 Baltimore B 10: Addenda 245 (463.51); BA 204733; Kunisch 1997, no. 307, pl. 102; Louvre G 145: ARV 463.50; BA 204732 (no image); Kunisch 1997, no. 313, pl. 104.

99 Munich 2657: Addenda 246 (475.267); вA 204946 (no image); Kunisch 1997, no. 507, pl. 163 (stage satyr in phallus costume, dancing next to a large column krater decorated with a wreath); Louvre MNE 961: ARV 475.261; BA 204940 (no image); Kunisch 1997, no. 509, pl. 164 (satyr performing an elegant dance next to a symposium table with a kantharos).

100 Basel Kä 410: Addenda 245 (463.53); BA 204735; Kunisch 1997, no. 128, pl. 44; Louvre G 145: ARV 463.50; Kunisch 1997, no. 313, pl. 104.

101 Fragments in several places: Para 377 (462.49); BA 204731; Kunisch 1997, 107 note 449, no. 109, pl. 39 .

102 Tarquinia RC 1118: Addenda 244 (Para 378.46bis); BA 275978 (no image); Kunisch 1997, no. 133, pl. 46; Baltimore B 10: Addenda 245 (463.51); BA 204733; Kunisch 1997, no. 307, pl. 102; Private collection: Para 377 (462.44); BA 204726 (no image); Kunisch 1997, no. 314, pl. 105 . 


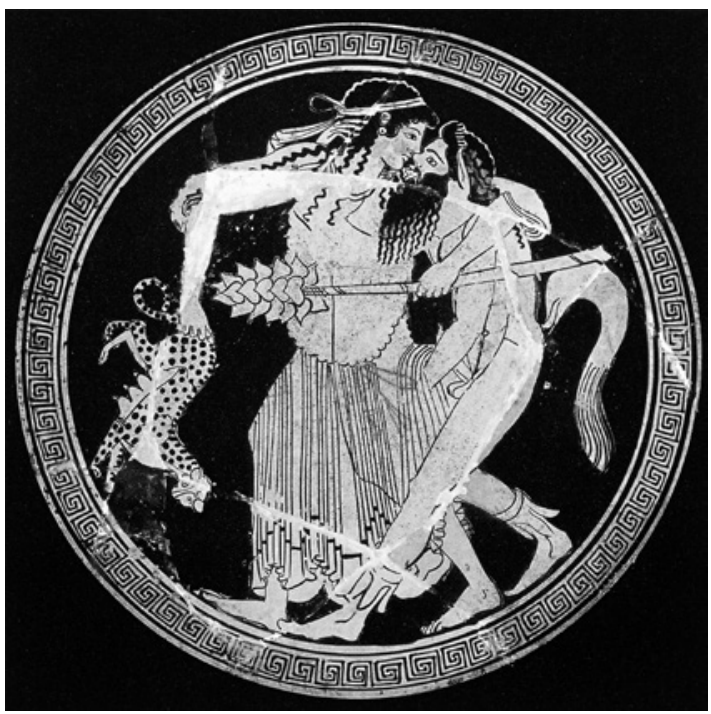

$a$

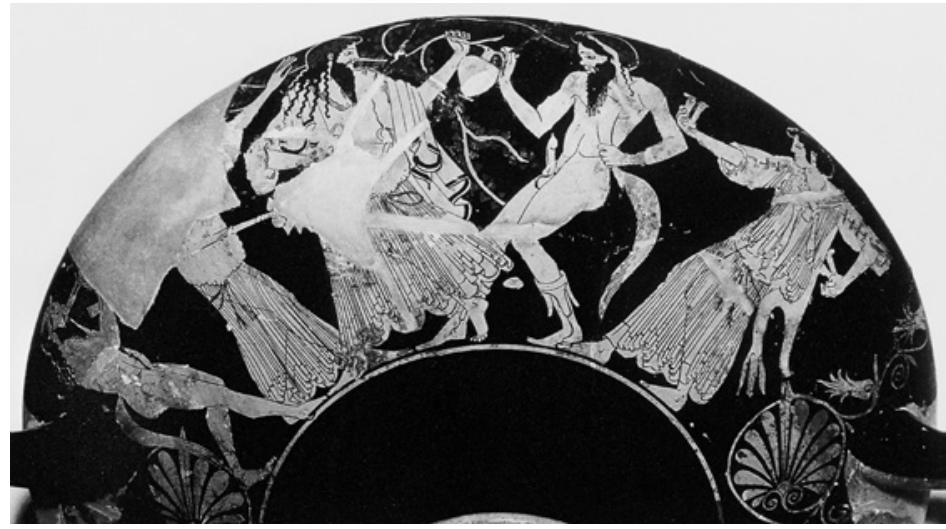

$b$

FIGURE 33 Cup, Makron, Paris, Louvre G 144 (Kunisch 1995, pl. 37).

a. medallion: satyr with female partner.

b. side A: Dionysos amidst his thiasos.

On the outsides of cups by Makron, we usually find Dionysos amidst the members of his thiasos. In one case he appears as a symposiast, but because of the fragmentary state of the cup it is impossible to determine who his comrade could be. The only remaining symposiast on the other side is definitely human. ${ }^{103}$ On a mental level, the presence of Dionysos at a human symposium

103 Oxford 1911.631: ARV 467.129; BA 204811; Kunisch 1997, no. 198, pl. 68. 
would in any case be considered entirely natural. Makron's famous skyphos shows how the artist saw Dionysos' position vis-à-vis the other gods. Here we see him, on the one side, with his ivy branch, as the central figure between Zeus and Amphitrite, set against Triptolemos, who is on the other side, seated in his winged chariot amidst the Eleusinian goddesses. ${ }^{104}$ The juxtaposition of these two culture heroes is probably also represented on a, unfortunately fragmentary, pelike by the Pan Painter - a more or less contemporaneous work of great artistic quality. ${ }^{105}$ The theme is likewise found in the work of the Niobid Painter. ${ }^{106}$ No less informative is an exquisite cup in Bochum (Figure 34). ${ }^{107}$ Its very damaged inside showed Athena welcoming Herakles, its outside has gods sitting enthroned. On one side we see Dionysos in the middle between Zeus and Poseidon, with Ganymede, a young woman-perhaps Ariadne-and Amphitrite standing next to them. The other side shows Ares in the middle between Apollo and Aphrodite. Artemis and Nike stand between them; Eros, coming from the right, is flying towards Aphrodite. Under the handles we can discern small panthers, ready to jump. Ever since Exekias, the assembly of the gods on the occasion of the apotheosis of Herakles is part of tradition. ${ }^{108}$ One of the most prominent examples, the Sosias cup in Berlin, has already been mentioned. ${ }^{109}$ What is unusual here is the conspicuous position of Ares and his opposition to Dionysos. Kunisch proposes a relationship with the Persian Wars: the work may be dated in the middle period of Makron's artistic career, around $48 \mathrm{o} \mathrm{BC} .{ }^{110}$ Kunisch' proposition is plausible and is, moreover, supported by the panthers under the handles; the panther symbolizes Asia. ${ }^{111}$ Dionysos is presented here as the counterpart of Ares, the god of war and victory. We may therefore presume Dionysos embodies cosmic peace, which would suit his role as the peace maker of the Olympic family (we could think of the return of Hephaistos) to perfection. As we will see, this characteristic of Dionysos will appear again and again, also in the later iconography.

Makron's oeuvre for the first time shows a subject that would be much in demand from 480 BC until well after the middle of the century: the handing

\footnotetext{
104 London E 140 (1873.8-20.375): Addenda 243 (459.3); BA 204701 (no image); Raubitschek/ Raubitschek 1982, 113; Kunisch 1997, no. 319, pl. 107; Clinton 1992, 124.

105 Malibu 81.AE.62: Robertson 1986, 72-88.

106 See below Chapter 5, note 3. We already find the juxtaposition of Dionysos and Triptolemos on black-figure vases of the early $5^{\text {th }}$ century, see Raubitschek/Raubitschek $1982,110$.

107 Bochum, Univ. S 1062: BA 13378 (no image); Kunisch 1997, 198, no. 352, pl. 118-119.

108 Mommsen 2002/03; Knell 1965, 47-54.

109 See above Chapter 2, note 81.

110 Kunisch 1997, 151.

111 Isler-Kerényi 2011a, $85 \mathrm{f}$.
} 


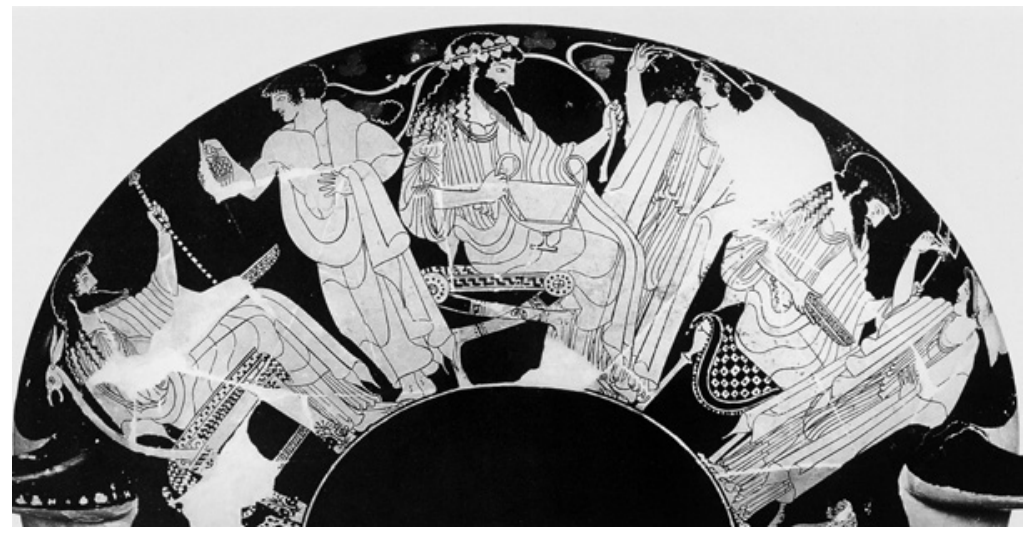

$a$

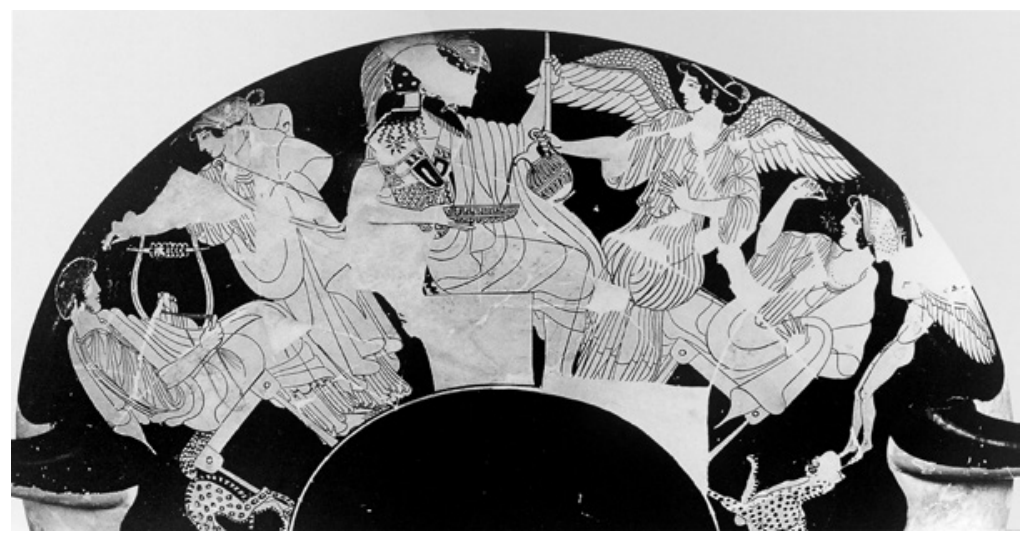

$b$

FIGURE 34 Cup, Makron, Bochum, Ruhr-Universität, Kunstsammlungen S 1062 (Kunisch 1995, pl. 119).

a. Dionysos.

b. Ares.

over of the child Dionysos to the nymphs. ${ }^{112}$ This motif will be discussed in more detail in one of the following chapters. ${ }^{113}$ Makron's famous Berlin cup presents an evident allusion to a Dionysiac ritual performed by women. We see Dionysos with a satyr playing the flute in the medaillon, as well as maenads

112 Athens, Acr. 2.325: Addenda 244 (460.20); BA 204701 (no image); Kunisch 1997, no. 437 , pl. 149 .

113 See below Chapter 5 , note 51 . 
dancing around an altar and a pillar-mask of the god on the outsides. ${ }^{114}$ This motif will also receive special attention below. ${ }^{115}$

In comparison with other vase types, the Dionysiac imagery of the cups from the first decade of the $5^{\text {th }}$ century seems rather uniform, despite some highly original examples. Like the prevalence of prototypical male figures, this may be explained from the relationship between this vase type and the symposium.

\section{Tentative Conclusions}

What conclusions may be drawn for the images of the vases of the late 6th and early $5^{\text {th }}$ century? Although very similar representations of encounter, thiasos, sexual confrontation, and symposiasts' bliss may be found throughout the period, no two versions are identical. The vase painters never contented themselves with the mindless repetition of familiar formulae, but were ambitious to give their personal interpretation: Dionysos and his world were apparently always considered topical and challenging. The thiasos and its mythological variant, the return of Hephaistos, were as important as ever, and have been innovatively depicted by the most prominent painters.

Compared to earlier stages, the many original representations of satyrs are a novelty. Lofty or base, solemn or grotesque, there seems hardly anything a satyr-alone or with companions - cannot do. ${ }^{116}$ The fact that the emergence of this new satyr imagery is contemporaneous with the introduction of the satyr play by Pratinas just before 500 вС cannot be without significance. ${ }^{117}$ Nevertheless, the hypothesis that there is a connection between vase paintings and certain satyr plays seems, apart for a few exceptions, less probable than the idea that both the introduction of the satyr play and the new importance of the satyr imagery reflect a general interest among the Athenians. ${ }^{118}$ One should keep in mind that the satyrs in the chorus of the satyr play were performed by citizens: in this perspective, identification with satyrs was not merely natural,

\footnotetext{
114 Berlin F 229o: Addenda 244 (462.48); BA 204730; Kunisch 1997, no. 345, pl. 116 f.

115 See below Chapter 6, note 10.

116 Compare Lissarrague 2013, 215: "La logique de ces images est plutôt de rendre étonnantes les pratiques les plus banales, et par là les remettre en question." Also Steinhart 2004, 127 (after his discussion of all satyr types and satyr scenes which occur in "Bildern mit Rollenspielen", p. 3): "Der Satyr kann ... als ein Spiegelbild unterschiedlichster Aspekte des Menschen verstanden werden.”

117 Voelke 2001, 18.

118 See Krumeich 1999, especially 47-51; Steinhart 2004, 101-104, 131.
} 
it was required. ${ }^{119}$ Satyr plays were part of the official performance repertoire of the City Dionysia, which makes us wonder whether this official exhibition of the identification of citizens with satyrs may have something to do with the recent reform of the polis by Kleisthenes. ${ }^{120}$ It is well known that one of the main points of this reform was a greater involvement of rural Attica in the polis. ${ }^{121}$ On the other hand, the Dionysiac iconography of the archaic period makes it clear that satyrs lived and acted in all three spheres of the mental world: in the city, in the wilderness, and also-especially as manufacturers of wine-in the rural countryside, the sphere that connects the two other antithetic zones. ${ }^{122}$ Seen against this background, the introduction of the satyr play, and the simultaneous rise of the figure of the satyr in the pictorial world of the vase painters is consistent and understandable. ${ }^{123}$

What about the representation of Dionysiac women during this period? Most frequently they are found in the context of the thiasos, as maenads dancing ecstatically or being pursued by satyrs. Sometimes the roles are reversed and the maenad is pursuing the satyr. ${ }^{124}$ It is far from clear whether the maenads view the often aggressive sexual advances of the satyrs with genuine distaste; their reaction could also be one of suggestive playfulness. ${ }^{125}$ Relatively often, especially on small neck-amphorae and pitchers, we find Dionysos approached by a woman who is not in the grip of madness; she is not a maenad, but a dignified figure carrying a libation vessel. ${ }^{126}$ In most cases it is impossible to decide whether this woman is meant to be Ariadne. ${ }^{127}$ On one of his pointed amphorae the painter and potter Syriskos ${ }^{128}$ gives her a name, Nymphaia,

119 Voelke 2001, 411: "Ainsi le public, tout en riant du spectacle du satyre, riait sans doute toute autant du spectacle de concitoyens jouant le satyre et de sa propre expérience, indirecte, d'une telle identité."

120 Voelke 2001, 18.

121 Voelke 2001, 31.

122 Isler-Kerényi 2007, $232 \mathrm{f}$.

123 Compare Spineto 2005, 353: "È comunque ai Dionysia megala ... che il meccanismo di definizione dell'identità di Atene attraverso le componenti della società che partecipano alla festa si manifesta nella maniera più chiara."

124 Basel Lu 45: Para 352 above; BA 352509 (Syriskos Painter, no image) and Naples, without number: ARV 287.25; BA 202596 (no image) (Geras Painter).

125 Lindblom 2011, 69 .

126 This formula may also be used for a single satyr, see for instance Munich 2343: ARV 531.27; BA 206003 (neck-amphora by the Alkimachos Painter): Dionysos with a woman carrying a thyrsos on the one side, and with a satyr carrying an askos on the other.

127 For this problem, see Sabetai 2011, $137 \mathrm{f}$.

128 Formerly known as the Copenhagen Painter: Weiss 1997, 104. 


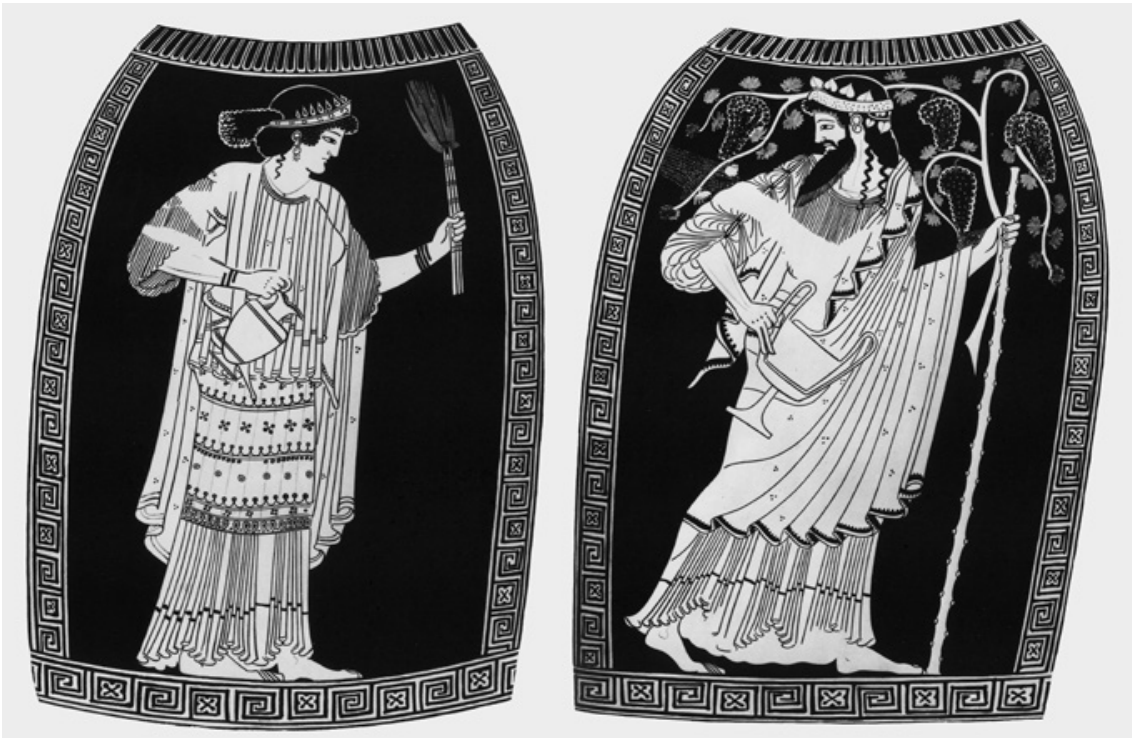

FIGURE 35 Amphora with twisted handles, Eucharides Painter, London, British Museum E 279 (BSA 18, 1912, pls. 11 [Dionysos] and 12 [woman]).

which is, however, a name that could refer to any nubile young woman. ${ }^{129}$ In any case, every woman approaching Dionysos in a ritual context could identify with Ariadne. ${ }^{130}$ This also holds true for the, less frequently depicted, woman who mounts a chariot in the company of Dionysos. ${ }^{131}$ The motif of the encounter is executed with great precision on both sides of an amphora with twisted handles by the Eucharides Painter, a contemporary of the Kleophrades Painter and the Berlin Painter. ${ }^{132}$ The large torch in the woman's hand explicitly refers to a ritual context (Figure 35).

As we have seen, satyrs may appear wherever humans are present, but their aspect is surprising and unsettling. Moreover, they can misbehave to the point of sacrilege. In contrast, the outward appearance of their female counterpartsthe women who interact with Dionysos and the satyrs, or dance as maenads

\footnotetext{
129 London E 350: Addenda 204 (256.2); BA 202921; Bonansea 2008, 116. For highly comparable images see a neck-amphora by the Syriskos Painter, Orvieto, Museo Civico 1040: ARV 261.20; BA 202974 and a pelike by the Deepdene Painter, Brussels R 250: ARV 501.34; BA 205621.

130 Isler-Kerényi 2007, 123.

131 For instance Naples 2410: Addenda 201 (239.18); BA 202367 (Myson). For a black-figure version: Villanueva Puig 2009b, $192 \mathrm{f}$.

132 London E 279: Addenda 199 (226.1); BA 202054.
} 
with Dionysiac attributes - is the same as that of women active in a different manner or a different place. ${ }^{133}$ Neither is it possible to ascribe a definite status to such Dionysiac women. ${ }^{134}$ As we will see, the Dionysiac ritual brings together women of various ages and positions. ${ }^{135}$ It is the male figure of the satyr that enables vase painters to put the societal role of men into perspective, to give it a comical or dubious twist. ${ }^{136}$ It must have pleased the Athenian as well as the Etruscan customers that the most bizarre fantasies could be depicted on vases. The phenomenon of the satyr provided them with a figure on which they could project everything that went against the norms and rules of civilized society, ${ }^{137}$ especially because satyrs could, as we will see, represent every age group from children to old men. ${ }^{138}$ Most of the time he is youthful; sometimes, however, his bald head and hairy body suggest a more mature age. Evidently, both young and elderly men could become satyrs, feel like satyrs or appear as satyrs.

It is illuminating that this figure belongs to the sphere of Dionysos. On the one hand Dionysos is responsible for all metamorphoses, those of the theater as well as those that inevitably belong to human life. On the other hand he is responsible for the order of the polis and for the regulated outbursts of disorder at the symposium and during festivals. Nevertheless, questions arise that should be kept in mind. Why does the satyr, ubiquitous on symposium vessels, not appear in sympotic poetry? ${ }^{139}$ On the other hand, why does he so often appear on pelikai? These were not characteristic symposium vessels, but were often used by women in their day-to-day chores. ${ }^{140}$ And if the satyr stands for immoderate and therefore reprehensible behavior (that must be accepted because it exists), ${ }^{141}$ how can we explain his important role as mediator between Dionysos and human beings? ${ }^{142}$

\footnotetext{
133 Lindblom 2011, $158 \mathrm{f}$.

134 Lindblom 2011, 145.

135 See below Chapter 6.

${ }_{13}$ As we have seen in the Introduction, Jaccottet 2003 draws similar conclusions on the basis of later Bacchic inscriptions.

137 The various details of this subject are extensively discussed in Lissarrague 2013.

138 See below Chapter 6 .

139 Catoni 2010, 258.

140 For the imagery of the pelike, see below Chapter 4 with note 63 .

141 Shapiro 2004; Catoni 2010, 262 and 287.

142 Isler-Kerényi 2004a, 96.
} 